\title{
On the Hybodus (Euselachii) from the Early Jurassic of Anina (Caraş Severin district, Romania)
}

\section{Emanuel Paul DICA* \& Vlad CODREA*}

\author{
Department of Geology, "Babeş-Bolyai” University, 1 Kogălniceanu, 400084 Cluj Napoca, Romania
}

Received February 2005; accepted July 2006



\begin{abstract}
A new Hybodus site from Romania is located at Anina, in the Pliensbachian - Middle Toarcian succession from Ponor quarry (Caraş-Severin district). The paper refers to a short description of the Hybodus teeth recently collected, followed by some considerations on hybodonts phylogeny and palaeoecology.
\end{abstract}

Key words: Hybodus, Euselachii, Getic Nappe, Reşița-Moldova Nouă sedimentary area, Anina, Banat, Early Jurassic.

\section{INTRODUCTION}

Sharks and generally Mesozoic fishes are rather rare in Romania. This kind of fossils is scarce and rare contribution on this topic can be noticed. However, some sites yielded such fishes as: Peştiş-Aleşd-Lugaşu de Sus area (Apuseni Mts., Inner Dacides), with Triassic (Anisian) assemblages including Hybodus cf. multiconus JAEKEL 1889, $H$. reticulatus AGGASSIZ 1837, Acrodus cf. lateralis AGASSIZ 1837, cf. Birgeria sp., "Colobodus" sp., Paleobates angustissimus AGASSIZ 1837, Serrolepis cf. suevicus DAMES 1888, Gyrolepis quenstedti DAMES 1888, "Saurichtys" sp., Ganoidei g. et sp. indet. (Jurcsák, 1976, 1977, 1978); undetermined fish remains from the Liassic at Moneasa (Apuseni Mts., Inner Dacides; Koch, 1900); "Orthacodus" (Sphenodus) and "Strophodus" from the Jurassic deposits from Valea Lupului (South Carpathians, Median Dacides, Getic Nappe; Simionescu and Barbu, 1943); Sphenodus tithonicus from the Late Jurassic (Tithonian) at Ghilcoş (Eastern Carpathians, Median Dacides; Koch, 1900); "Sphaerodus gigas" AGGASIZ 1837 from the Late Jurassic (Tithonian) limestones exposed at Tureni (Apuseni Mts., Transylvanides; Koch, 1900; Simionescu and Barbu, 1943) and the Late Jurassic from Ghilcoş (Koch, 1900); Gyrodus, Coelodus from the Early Cretaceous at Cernavodă (South Dobrogea, Moesian Plateform; Simionescu and Barbu, 1943); Lamna sp. in the Cretaceous from Steierdorf (now, included in Anina; South-Western Carpathians, Median Dacides, Getic Nappe; Koch, 1900); Eotrigonodon sp. from the Early Cretaceous (Barremian-Aptian), Reşița-Moldova Nouă sedimentary area (South-Western Carpathians, Getic Nappe; Dica et al., 1998); Pycnodus sp. (?), from the Late Cretaceous at Borod (Vad-Borod post-Laramian Basin; Koch, 1900); Lepisosteus sp., Characidae indet. in the Latest Cretaceous (Maastrichtian; Hațeg Basin, Grigorescu and Csiki, 2002).
In addition, one of us (P.D.) had the opportunity to notice a still unpublished Mesozoic fish: Allestidae indet. (possibly a new taxon) from the Latest Cretaceous at NălațVad (Hațeg Basin).

A team of geologists from "Babeş-Bolyai" University in Cluj, in a field mission carried out some years ago at Ponor open pit near Anina (Banat, Caraş-Severin district, Fig. 1), succeeded in collecting some shark teeth and scales from the Liassic rocks cropping out there. The fossils had been collected from the Ponor dump (Fig. 2). However, the matrix is extremely peculiar, involving bituminous shale. This kind of rock is specific only for the so-called Uteriş Member, once exploited for combustion in Anina power plant. In this manner, the level that yielded the fossils is doubtless.

As these fossils are so rare in our country, they are worth to be described in this paper. The fossils are housed in the vertebrate paleontology collection at PaleontologyStratigraphy Museum, "Babeş-Bolyai" University Cluj (abr.: P.S.M. U.B.B.).

\section{GEOLOGICAL SETTING}

The Getic Nappe erected in the Laramian tectogenesis is among the main structural elements of the Western Romanian Carpathians. The nappe involves a metamorphic basement intruded by magmatites, covered by Upper Paleozoic and Mesozoic sedimentary deposits. Subsequently, this sedimentary blanket was eroded and can actually be observed only on restricted areas. The most representative area is located between Reşița and MoldovaNouă (Caraş-Severin district).

After a Paleozoic sedimentation, a new sedimentary cycle began in the Lower Jurassic (Mutihac et al., 2004). The evolution of the Liassic sedimentation (Bucur, 1991) 
involves on its base continental formations (alluvial and fluviatile with lacustrine episodes systems), beginning with gritty conglomerate (Dealul Budinic Member; Hettangian pro-parte) followed by gritty clay with a coal lens, or with coal lenses (the Valea Tereziei Member; Late HettangianSinemurian) and leafy bituminous black clays, rich in organic matter, with coal lenses and spherosiderite concretions (the Uteriş Member; Pliensbachian-Middle Toarcian). All these members are included into the Steierdorf Formation. The continental deposits are followed by a marine succession belonging to Valea Zânei Formation (Toarcian-Early Callovian).

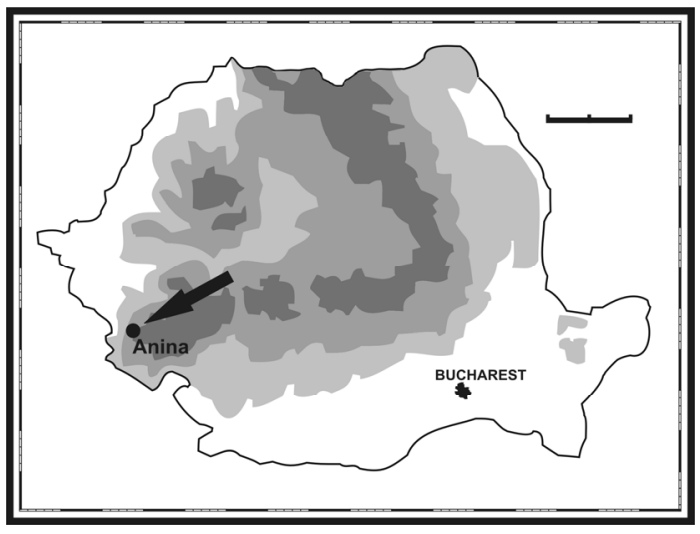

Fig. 1. Location of the site.

Concerning the lithostratigraphic rank of the Uteriş Member there are two different points of view. Bucur $(1991,2001)$ interpreted this succession as a member of the Steierdorf Formation, opinion also agreed by Popa (2000 a, 2001). On the other hand, Stănoiu et al. (1997) refined the stratigraphy of the Reşiţa Basin, considering Uteriş as a distinct formation, probably due to its very peculiar lithology. For this unit they consider a restricted lacustrine system as paleoenvironment. However, Popa (2000 a) does not exclude even a possible marine origin.

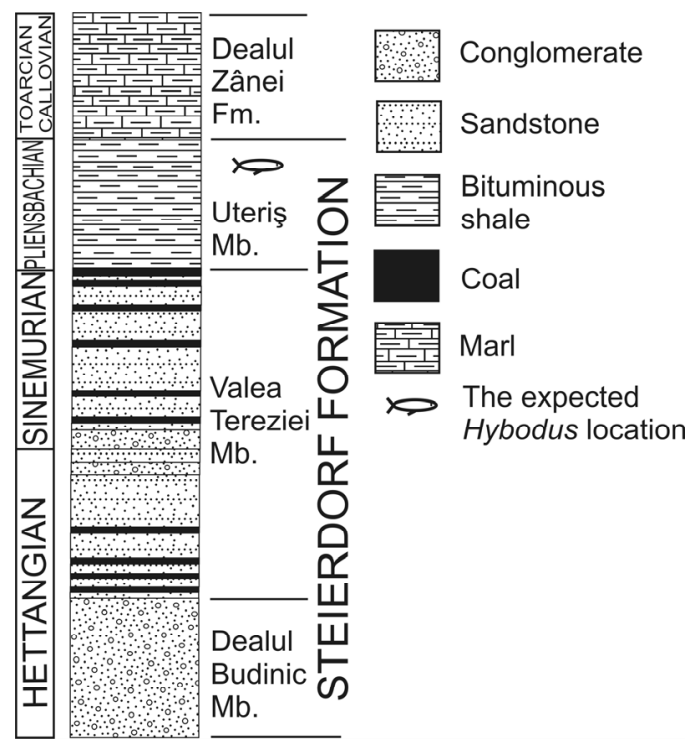

Fig. 2. Lithostratigraphic log of Ponor quarry (according to Popa, 1999).

This sedimentary evolution of the Getic domain can be compared in Romania with another sedimentary realm located in the Bihor Unit (Inner Dacides). There, a similar tendency of a gradual transition from continental to marine environments is recorded in the Hettangian-Sinemurian succession in Şuncuiuş Formation (Mészáros et al., 1999). However, a marine basin was already installed there since the Pliensbachian.

From the Liassic continental formations from Reşița Basin, rich assemblages are known, involving almost exclusively micro- and macroflora (Popa, 2001). Popa $(2000 \mathrm{~b})$ also described from Steierdorf Formation tetrapod tracks, related to Batrachopus cf. deweyi OLSEN AND PADIAN, 1986.

\section{PALEONTOLOGY}

The terminology and systematics are according to Cappetta (1987).

Class Chondrichthyes HUXLEY, 1880

Subclass Elasmobranchii BONAPARTE, 1838

Cohorte Euselachii HAY, 1902

Superfamily Hybodontoidea ZANGERL, 1981

Family Hybodontidae OwEN, 1846

Genus Hybodus AgAssIz, 1837

Type - species: Hybodus reticulatus AGASSIZ 1837

\section{Hybodus sp.}

Material - 5 teeth (P.S.M.U.B.B. V 416 - V 420). Description

The teeth measure up to $7 \mathrm{~mm}$ in length and $3 \mathrm{~mm}$ in high (Fig. 3). There are three types of teeth reflecting the position into the mouth, i.e. teeth with 1,2 and 3 pairs of cusps. The central cusp and the lateral ones are pyramidal, with a star aspect. The central cusp is upright or slightly inclined distally (5-10 degrees). It has 2 cutting edges, as well as the lateral cusps. In occlusal view the central cusp is slightly curved labio-lingually. The lateral cusps are 2-3 times lower than the central one. The vertical ridges are rare, reaching the apex of all cusps. The ridges are very bossy, even edged, weakly bifurcated on labial view and almost vertical and much more marked on the lingual side. In the lingual shoulder there are coalescences at the base of vertical ridges, forming an impersistent longitudinal ridge. There are no labial nodes on the labial side. We can not notice the presence of any lingual shelf. None of the teeth preserved the root.



Fig. 3. Hybodus sp., labial view (scale: $1 \mathrm{~mm}$ ).

Remarks

A lot of Hybodus species were described world-wide upon teeth or more or less complete skeletons. The genus ranges from Middle Triassic to Late Cretaceous. The most common species in the Early Jurassic from Europe are:

H. cloacinus QUENSTADT, 1858 - Rhaetian: France; ?Sinemurian: England; Belgium, and Germany;

H. delabechei (CHARLESWORTH, 1839) - Hettangian - 
Sinemurian: England; Pliensbachian: Denmark and France; H. grossiconus AGASSIZ, 1837 - Toarcian: Luxemburg; Bathonian: England; Callovian: France;

H. hauffianus FRAAS, 1895 - Toarcian: Germany, Luxemburg;

H. medius AgAssiz, 1843 - Sinemurian: England;

H. raricostatus AGASSIZ, 1843 - Sinemurian: Belgium, England and Germany;

H. reticulatus AgASSIZ, 1837 - Bathonian: England; Hettangian: Luxemburg; Sinemurian: Belgium, Pliensbachian, Denmark, and Sweden; Liassic: England.

Duffin (1993) provided a dichotomous key for the isolated teeth from the Early Jurassic of Lyme Regis (England). Duffin (1997) and Delsate (1997) add new determination keys for the Lower Jurassic Hybodus species.

According to these keys we noticed the following differences between the teeth from Banat and the Lower Jurassic species:

- the main difference is the teeth size, smaller than in the mentioned species;

- another important difference is the shape of the principal cusp almost pyramidal in our material, while being more slender in $H$. reticulatus and $H$. cloacinus. It could be closer to $H$. medius and $H$. delabechei, however these species are different due to the presence of not so lower lateral cusps;

- the presence of labial nodes is characteristic in $H$. hauffianus and $H$. delabechei, $H$. medius and $H$. cloacinus. In our material there are no labial nodes, as in $H$ reticulatus.

- bifurcated ridges appear in our material, as in $H$. cloacinus and $H$. medius. There are non-bifurcating ridges in $H$. hauffianus.

- coalescences in the base of the vertical ridges form an impersistent longitudinal ridge in the lingual face of the crown. This ridge is present in H. hauffianus, as well in our material, but is absent in $H$. reticulatus

- vertical ridges are entire in our material, as in $H$. reticulatus, never broken as they appear sometimes in $H$. hauffianus

- the lingual shelf is not present in our material; it is present in larger teeth of $H$. reticulatus, in $H$. delabechei, $H$. raricostatus and it is absent in $H$. hauffianus

We noticed some resemblances with the "Hybodus" cf. minor teeth from the Early Toarcian of Aubange (Belgium; Delsate and Godefroit, 1995). On the basis of teeth morphology and enameloid microstructure, Cunny and Risnes (2005), transferred this taxon in to the Rhomphaiodon genus that belong to Synechodontiformes. The differences refer mainly to the ornamentation, there are no ridges bifurcated in Rhomphaiodon minor. In our material the ridges are very bossy, resulting in pyramidal cusps, with a star like aspect.

In Pliensbachian - Toarcian of Europe we noticed the presence of the following species:

- Lower Toarcian of Aubange (Belgium, Delsate and Godefroit, 1995) - In "The first layer with bones debris": Rhomphaiodon minor, $H$. cf. delabechei, Hybodus sp.

- Torcian of Luxembourg (Delsate, 1995, 1997) - In the "Grandcourt bituminous shales" (Harpoceras falcifer zone) is present only $H$. hauffianus; in "Grandcourt marls with septarias" (Hildoceras bifrons zone, Lower Toarcian) there are several species: $H$. hauffianus, $H$. grossiconus, $H$. cf. grossiconus, Hybodus sp.
- Toarcian bituminous shales at Holzmaden (SW Germany, Duffin, 1997; Delsate, 1998) - H. hauffianus

- Toarcian Somerset (Great Britain) - Hybodus sp (Delsate, 1998); - Hybodus sp. in the Falcifer Zone / Exaratum Subzone (Arkell, 1970)

- Late Pliensbachian Chassilé (Sarthe / France, Biddle, 1993) - H. delabechei

- Toarcian Lorraine (France, Paris Basin) - Hybodus sp. (Lamaud, 1974); - Hybodus cf hauffianus in the Falcifer Zone / Nancy (Delsate and Wild, 2000).

In the Uteris Member Popa (1999) identified the range zone with Carpolithes liassicus, specifical for Pliensbachian. The presence of Sagenopteris sp. extends the range of the formation up to middle Toarcian. He considered for the Uteriş Member sediments a deep, anoxic, aquatic environment, a lake environment or possibly a marine one.

Delsate and Godefroit (1995) suggested that in the Early Toarcian a global renewal of the shark fauna could be remarked. Because the Uteriș Member ranges between Pliensbachian - and Middle Toarcian, it is possible that the Banat teeth belong either to a relative of $H$. hauffianus (characteristic for Lower-Middle Toarcian), or to an earlier Lower Jurassic species. Unfortunately we couldn't assign these teeth with confidence to a certain species.

The presence of Hybodus in this geological context suggests at least an episodic connection during the deposition of the Uteriş Member, between Reşița Basin and an open sea realm, probably marine. In Europe there are similar bituminous deposits in Lower-Middle Toarcian of SW Germany and Luxembourg. We couldn't compare these deposits with those of Uteriş Member, which are poor in fossil diversity and abundance.

There are two primary dentition types recognized in Hybodus: clutching type and tearing type, reflecting various diets. The clutching type dentition (characteristic for the Banat teeth), involves sharp teeth adapted for catching fast prey like fish and squid. The Hybodus species were mainly marine sharks. Some were also recorded in brackish and freshwater environments (Europe, Asia, Africa and North America). In Late Triassic - Early Liassic, the Hybodus species reached about $2-2.5 \mathrm{~m}$ long. It is difficult to estimate the exact size of Anina specimens - the teeth being smaller-, but one can approximate a length less than 1 meter.

Once, a lot of forerunners believed that all modern sharks descended from hybodonts, considering Hybodus as a direct ancestor of the family Heterodontidae (bullhead sharks). Recently, Maisey et al. (2004) suggested that hybodonts and neoselachians (including all modern sharks and batoids) are monophyletic and sister groups. He also considers that Synechodus (included in Neoselachii, Synechodontiformes) is more closely related to modern sharks than hybodonts.

Acknowledgements. Authors are fully indebted to: Matei Vremir from "Babeş-Bolyai" University in Cluj Napoca for his help in collecting the fossils and Dr. Mihai Popa, University of Bucharest, for providing valuable references und useful suggestions on Reşiţa Basin geology and paleontology. We wish to thank also Dr. Dominique Delsate for reviewing this paper, for bibliography and his valuable advices. 


\section{R E F E R E N C E S}

Arkell, W.J. 1970, The Jurassic system in Great Britain. Oxford University Press, London, $681 \mathrm{pp}$.

Agassiz, L. 1833-1843, Recherches sur les Poissons fossiles-I, I, III, Neuchatel, pp 1420.

Biddle, J.P. 1993, Quelques élasmobranches du Domérien (Jurassique inférieur) de la région du Mans (Sarthe, France). Cossmanniana, 2: 61-66.

Bucur, I.I. 1991, Proposition pour une nomenclature formelle des dépôts Paléozoïques et Mésozoïques de la zone Reșița-Moldova Nouă (Carpathes Méridionales, Roumanie). Studia Universitatis Babeş-Bolyai, Geologia, 36 (2): 3-14.

Bucur, I.I. 2001, Paleozoic and Mesozoic formations in the Reşița-Moldova Nouă zone (South Carpathians). In Field Trip Guide, $4^{\text {th }}$ Regional Meting of IFAA (Bucur, I.I., Filipescu, S., Săsăran, E., Eds.), Cluj-Napoca, 6374.

Cappetta, H. 1987, Mesozoic and Cenozoic Elasmobranchii, Chondrichthyes II. In Handbook of Paleoichthyology H.(Schultze, P., Ed.), Stuttgart - New York: Gustav Fischer Verlag, 193 pp.

Cappetta, H., Duffin, C.J. \& Zidek, J. 1993, Chondrichthyes. In The Fossil Record 2, (Benton, M.J., Ed.), London: Chapman and Hall, 593-609.

Cuny, G., Risnes, S. 2005, The enameloid microstructure of the synechodontiform sharks (Chondrichthyes: Neoselachii).Vertebrate paleontology, 3 (2): 19 pp.

Delsate, D. 1995, Chondrichthyens mésozoïques du GrandDuché de Luxembourg. Belgian Geological Survey. Professional Paper 278 (Elasmobranches et Stratigraphie): 11-22.

Delsate, D., Duffin, C.J. 1993, Chondrichthyens du Sinémurien de Belgique. Belgian Geological Survey. Professional Paper 264 (Elasmobranches et Stratigraphie): 103-136.

Delsate, D., Godefroit, P. 1995, Chondrichthyens du Toarcien inférieur d'Aubange (Lorraine belge). Belgian Geological Survey, Professional Paper 278 (Elasmobranches et Stratigraphie): 23-43.

Delsate, D. 1997, Chondrichthyens mésozoïques du Grand Duché de Luxembourg: Compléments. Travaux scientifiques du Musée d'Histoire Naturelle de Luxembourg, 27: 53-99.

Delsate, D. 1999, L'Ichthyofaune du Toarcien luxembourgeois. Cadre général et Catalogue statistique. Travaux Scientifiques du Musée national d'Histoire naturelle de Luxembourg, 30: 101 pp.

Delsate, D., Wild, R. 2000, Première découverte d'un reptile volant déterminable (Pterosauria, Dorygnathus cf banthensis) du Toarcien inférieur (Jurassique inférieur) de Nancy (Lorraine, France): Bulletin de l'Académie lorraine des Sciences, 39: 3- 14.

Delsate, D., Duffin, C. \& Weis, R. 2002, A new microvertebrate fauna from the Middle Hettangian (Early Jurassic) of Fontenoille (Province of Luxembourg, South Belgium). Memoirs of the Geological Survey of Belgium 48: 3-83.

Dica, E.P., Bucur, I.I. \& Strusievicz, R.O. 1998, First mention of Eotrigonodon (Osteichthyes, Plectognathi) in Lower Cretaceous deposits from Romania. Studia Universitatis Babeş-Bolyai, Geologia, 42 (2): 23-27.
Duffin, C.J. 1993, Teeth of Hybodus (Selachii) from the Early Jurassic of Lyme Regis, Dorset, Southern England: preliminary note. Belgian Geological Survey, Professional Paper 264 (Elasmobranches et Stratigraphie): 45-52.

Duffin, C.J. 1997, The dentition of Hybodus hauffianus Fraas, 1895 (Toarcian, Early Jurassic). Stuttgarter Beitrage zur Naturkunde, Series B, 256: 1- 20.

Grigorescu D., Csiki Z. 2002, Geological introduction to the Uppermost Cretaceous continental formations with dinosaurs and other vertebrates of the Hateg Basin. In The $7^{\text {th }}$ European Workshop of Vertebrate Palaeontology, Sibiu, Abstracts Volume and Field Guide: 51-57.

Jurcsák T. 1976, Noi descoperiri de reptile fosile în Triasicul de la Aleşd. Nymphaea, IV: 67-105.

Jurcsák T. 1977, Contribuții noi privind placodontele şi sauropterygienii din Triasicul de la Aleşd (BihorRomânia). Nymphaea V: 5-30.

Jurcsák T. 1978: Rezultate noi în studiul saurienilor fosili de la Aleşd (Bihor, România). Nymphaea VI: 15-60.

Koch A., 1900. Systematische Übersicht der fossilen Wirbeltierreste der Lander der Ungarischen Krone. Magyar orvos természet-vizsgálat, Vándorgy Munka, 30: 526-560.

Lamaud, J. 1974, Sélaciens du Lias de l'Est de la France. Bulletin de la Société d'histoire naturelle du Pays de Montbéliard, 119-124.

Maisey, J.G., Naylor, J.P. \& Ward, D.J. 2004, Mesozoic elasmobranchs, neoselachian phylogeny and the rise of modern elasmobranch diversity. In Mesozoic fishes 3 Systematics, Paleoenvironments and Biodiversity. (Arratia, G., Tintori, A., Eds.): Munchen, 17-56.

Mészáros, N., Barbu, O. \& Codrea, V. 1999, The Nannoplankton from the Şuncuiuş Formation (Lower Liassic; Pădurea Craiului Mts, Western Romania). Studia Universitatis Babeş-Bolyai, Geologia 44 (2): 89101.

Mutihac, V., Stratulat, I.M. \& Fechet, M.R. 2004, Geologia României. Ed. Didac. şi Pedag., Bucureşti, 249 pp.

Popa, E.M. 2000 a, Aspects of Romanian Early Jurassic paleobotany and palynology. Part III. Phytostratigraphy of the Getic Nappe. In Acta Palaeontologica Romaniae 2 (Bucur, I.I., Filipescu, S., Eds.), Cluj Napoca, $377-$ 386.

Popa, E.M. 2000 b, First find of Mesozoic tetrapod tracks in Romania. In Acta Palaeontologica Romaniae 2 (Bucur, I.I., Filipescu, S., Eds.), Cluj Napoca, 387-390.

Popa, E.M. 2001, Ponor SSSI (Site of Special Scientific Interest). Lower Jurassic Paleoflora. In Field Trip Guide, $4^{\text {th }}$ Regional Meting of IFAA (Bucur, I.I., Filipescu, S., Săsăran, E., Eds.), Cluj-Napoca, 167-172.

Simionescu, I., Barbu, V. 1943: Paleontologia României. Editura Cartea Românească, Bucureşti, 120 pp.

Stănoiu, I., Popa, M., Diaconița, D., Țicleanu, M., Dinulescu, C. \& Balabaş, T., 1997, The Liassic from Reşița and Sirinia basins. International Symposium „Geology in the Danube Gorges”, Donji Milanovac Orşova, 249-254.

Woodward, A.S. 1889, Catalogue of the Fossil Fishes in the British Museum (Natural History). Part I Elasmobranchii. British Museum of Natural History, London, 474 pp. (+47 pl.). 